\title{
The Effect Of Compensation, Environment And Leadership Style On Employee Spirit And Performance Through Motivation
}

OPEN ACCESS ISSN 2528-4649 (online) ISSN 2338-4409 (print)

Reviewed by: Prof. Dr. Zarah Puspita, S.Sos., SE,

M.Si

${ }^{*}$ Correspondence: Muhammad Yani Muhammad_yani@umsida.ac.idi Received:December 27, 2020 Accepted: February 29, 2021 diterima Published: March 31, 2021 JBMP: Jurnal Bisnis, Manajemen dan Perbankan. Vol: $7 /$ No. 1

doi:10.21070/jbmp.v7i1.1337

\section{Muhammad Yani}

Faculty of Business, Law, and Social Sciences, University of Muhammadiyah Sidoarjo, Indonesia

This study examines the effect of compensation, environment, and leadership style on employee work passion and performance through motivation studies at PT. EX. A total of 95 respondents are employees of the production section of PT. EX was involved in this research. They are selected using a non-probability sampling technique from the population or production employees. The data analysis technique used the Structural Equation Modeling (SEM.) Partial Least Square (PLS) approach using the SmartPLS version 3.0 software. The results showed that compensation and work environment positively and significantly affected work motivation, compensation, and work environment completely and affected substantially work passion. Work motivation had a positive and significant effect on employee performance and employee work passion. Leadership style does not affect work motivation, employee performance, and work passion. Compensation and work environment do not affect employee performance. Compensation has a positive and significant effect on employee performance through work motivation. The work environment has a positive and significant effect on employee performance through work motivation. Compensation has a positive and significant effect on work motivation through work motivation; the environment positively and significantly affects work motivation through work motivation. Also, motivation cannot mediate the relationship between leadership style and employee performance, and motivation cannot mediate the relationship between leadership style and work passion.

Keywords: Compensation, environment, leadership style, work passion, employee performance, employee motivation. 


\section{INTRODUCTION}

As a result of the 4.0 Industrial Revolution, many factories have started implementing internet network systems to facilitate internal information, employee supervision, and bookkeeping. Companies must always exist and survive to face competition. Besides, human resources must have high performance. Human resources' role is significant to compete and survive challenges because human resources are seen as a determining element in the business development process and realizing company goals; therefore, human resources must be prepared thoroughly, directed, and integrated. Human resources or employees are the most expensive assets owned by the company to be managed carefully. Thus the management includes providing compensation, a comfortable environment, a good leadership style, and employee motivation. The employees will produce good performance if they are compensated fairly to avoid a social gap between employees, impacting decreased performance.Kinerja berkaitan dengan perilaku kearah pencapaian tujuan atau misi organisasi, atau produk dan jasa yang dihasilkan dari perilaku tersebut (Hughes, Ginnett dan Curpy, 2015:311). Selain itu, ada faktor-faktor yang mempengaruhi gairah kerja menurut Nitisemito (Murtisaputra \& Ratnasari, 2018) adalah kepemimpinan, motivasi, komunikasi, hubungan manusiawi, kompensasi dan lingkungan kerja.

Hasibuan (2005: 94) stated that work passion is the desire and seriousness of a person to do a job well and be disciplined to achieve maximum work performance. Some factors cause work passion, such as a harmonious relationship between leaders and subordinates, especially between day-to-day work leaders directly dealing with and dealing with associates, officers' satisfaction with their duties and jobs because they get a fully liked task. There is an atmosphere and a working climate that is friendly to the members of the organization, if the employees who are related to work daily, the sense of use for the achievement of organizational goals which is also a common goal that must be realized together as well, there is a level of economic satisfaction and other value satisfaction adequate as a reward that is felt to be fair to the efforts that have been given to the organization, as well as the peace of mind, assurance of certainty and protection against everything that can endanger personal and career paths (Zainun, 1991). According to (Hasibuan, 2012) compensation for all income in the form of money, direct or indirect goods received by employees in return for services rendered to the company.

To increase employee work passion, companies must pay attention to employee needs, such as a decent salary, the relationship between superiors and employees, and a comfortable work environment. According to Shidhaye R.V et al. (2011), the work environment is an essential factor in maintaining employee work passion. The work environment has a tremendous influence on an individual in increasing employee work passion.

According to Hasibuan (2009: 170), leadership is the way a leader influences subordinates' behavior so that they are willing to work together and work productively to achieve organizational goals. The effective leader recognizes the essential strengths in an individual or group and is flexible in improving the entire organization's performance. According to Fikri (2008), without effective leadership, individuals or groups tend to have no direction, are dissatisfied, and are less motivated. Prasetyo, Ndaru (2012), and Reni (2015), in their research, show that leadership style has a positive and significant effect on employee work motivation. On the other hand, Sibali, Nawawi. D. (2011) showed that leadership did not affect employee motivation.

Motivation is a condition that drives to achieve motivation goals (Mangkunegara, 2004: 93). Nawawi (2005: 359) stated that there are two kinds of motivation based on the source, namely intrinsic and extrinsic motivation. Intrinsic motivation comes from within the worker as an individual, in the form of awareness of the importance or benefit or meaning of the work. Extrinsic motivation encourages workers from outside themselves as individuals. This can be a condition that requires workers to carry out their work to the maximum.

\section{METHOD (FOR RESEARCH ARTICLE)}

The population in this study were the operators of the production division at PT. EX, a manufacturing company, engaged in the production of shoes in Sidoarjo. The sample was taken using a non-probability sampling technique. This sampling technique does not provide equal opportunity for each element or member of the population to be selected as a sample. The sample used in this study was purposive sampling. Purposive sampling is the sample (respondents) determination with criteria, such as production employees, permanent employees or contract employees who have been appointed as permanent employees at least one year after appointment, production employees who occupy the operator position. The number of samples used was 95 employees.

This study's primary data comes from the object under investigation directly based on a questionnaire distributed to respondents. Each respondent was asked to answer the statements made using the ordinal scale type and the measurement scale using the Likert scale. Alternative answers to the instrument are 1) Strongly agree (SS) with a score of 5.2) Agree (ST.) Score 4. 3) Doubt (RG.) Score 3. 4) Disagree (TS.) Score 2.5) Strongly Disagree (STS.) Score 1, (Sugiyono, 2011: 94).

The collected data were then analyzed using the Structural Equation Modeling (SEM.) Partial Least Square (PLS) approach with the SmartPLS version 3.0 software. PLS, which is a component or variant-based structural equation model. PLS can be used to explain whether there is a relationship between latent variables (prediction). PLS can also be used to confirm the theory (Chin and Newsted 1999). Besides, PLS can also be used to explain whether there is a relationship between latent variables. Confirmatory analysis of factors for constructs with reflexive indicators by looking at each indicator's validity serves to test the construct's reliability.

Evaluation of the Measurement Model (Outer Model) is carried out by conducting a validity test. The criterion for indicator validity is measured by convergent validity, including Loading Factor, Average Variance Extracted (AVE), and discriminant validity, including Cross Loading, Average 
Variance Extracted (AVE) square root, and correlation between latent constructs. Composite Reliability and Cronbach's Alpha measure construction reliability. Evaluation of the Measurement Model (Inner Model) in assessing the structural Model with PLS is evaluated by looking at the percentage of variance described, namely by looking at the RSquare for endogenous latent constructs as the predictive strength of the structural model. The interpretation is the same as the interpretation in the OLS regression. Changes in the RSquare value can explain the effect of certain exogenous latent variables on endogenous latent variables whether they have a substantive effect. The R-Square values of $0.75,0.50$, and 0.25 can be concluded that the model is strong, moderate, and weak. The PLS. R-Square results represent the sum of the variance of the constructs described by the model. Apart from seeing the $\mathrm{R}$ square value, you can also see the $\mathrm{Q} 2$ predictive relevance value. This technique can represent the synthesis of cross-validation and fitting functions. The value of $\mathrm{Q} 2>0$ then has predictive relevance, whereas if the value of $\mathrm{Q} 2<0$, then the model has less predictive relevance. The Q2 predictive relevance values $0.02,0.15$ and 0.35 mean that they are weak, moderate, and strong. (Ghozali dan Latan, 2015:81).

\section{RESULTS}

Sources of data used in this study came from answers to questionnaires distributed as many as 95 to employees of the production division of PT. EX, with the male gender amounting to $0.19 \%$, and female amounting to $0.81 \%$. While the percentage of parts: Upper amounted to $0.61 \%$, Closing amounted to $0.13 \%$, Fullshoe amounted to $0.06 \%$, Injection amounted to $0.06 \%$, Desma amounted to 0.04 and Finishing amounted to 0.09

\section{Measurement Evaluation (Outer Model)}

\section{Convergent Validity}

All indicators provide outer loading above 0.70 or meet convergent validity. Meanwhile, several indicators have outer loading values below 0.70 or invalid, namely: compensation indicators (KP3), leadership style indicators (GK2, GK3, and GK5), and performance indicators (K3, K4, and K5). Because it does not meet the criteria for convergent validity, the indicator is excluded from the model.

\section{[Table 1 about here.]}

Based on the AVE output results from Smart PLS in Table 1., it can be seen that the results of all constructs have a value> 0.50 so that each construct has met the validity requirements.

\section{Discriminant Validity}

The level of construct validity can be measured in a second way, namely using discriminant validity, as presented in Table 2 below:
[Table 2 about here.]

Table 2.shows that each construct's loading factor value is in bold numbers whose value is greater than the correlation between constructs; it can be concluded that each construct has good discriminant validity.

\section{Composite Reliability}

The composite reliability and Cronbach's alpha values for each construct are presented in Table 3 as follows:

[Table 3 about here.]

The Cronbach's Alpha value produced by all constructs is very good because the value is above $>0.70$, so it can be concluded that the construct indicator is reliable or it can be said to meet the reliability test. The Composite Reliability value generated by all constructs is very good because it is above> 0.70 , so it can be concluded that all construct indicators are reliable or meet the reliability test.

\section{Structural Model Equation (Inner Model)}

The estimation has met the criteria for the Outer Model. The next step is to test the structural Model (Inner Model). According to (Ghozali, 2011), the purpose of evaluating the structural Model (Inner Model) is to predict the relationship between latent variables. Analysis using Smart PLS 3.0 software shows the output results of the loading factor construct structure model, which is shown in the following figure:

[Figure 1 about here.]

In assessing the inner Model with SmartPLS, it can be seen that the value of $\mathrm{R}$-Square $\left(\mathrm{R}^{2}\right)$ for each latent variable is endogenous. R-square coefficient $\left(R^{2}\right)$ shows how much exogenous variables explain the endogenous variables. The value of $R$-Square $\left(R^{2}\right)$ is zero to one.

\section{R-Square $\left(\mathbf{R}^{2}\right)$ Test}

\section{[Table 4 about here.]}

From the table above, it can be seen that the R Square value for the employee performance variable is $0.292 \mathrm{~m}$, which means that the model is weak. Work Motivation is 0.712 , which means that it is in a strong category. Meanwhile, the work passion variable is 0.6738 , which means that it is in a strong category.

\section{Path Coefficient}


[Table 5 about here.]

The path coefficient table above shows that the compensation variable has a significant effect on motivation. The resulting t-statistic value is 5.115> 1.96, and the probability is above 0.05 . The compensation variable has a significant effect on work passion. The resulting t-statistic value is 2.580> 1.96 and the probability <0.05. Work environment variables have a significant effect on work motivation. The resulting t-statistic value was 9.102> 1.96 and the probability $<0.05$. Work environment variables have a significant effect on work passion. The resulting t-statistic value is $2,450>1.96$, and the probability $<0.05$. The work motivation variable has a significant effect on employee performance. The resulting t-statistic value is $2.718>1.96$, and the probability is $<0.05$. The work motivation variable significantly affects employee work passion; the resulting tstatistic value is $3.019>1.96$, and the probability $<0.05$.

The leadership style variable does not affect employee performance. The resulting t-statistic value is $0.503<1.96$, and the probability is $>0.05$. The leadership style variable does not affect work motivation, and the resulting t-statistic value is $1.362<1.96$, and probability> 0.05. The leadership style variable does not affect work passion. The resulting t-statistic value is $0.442<1.96$, and the probability is $>0.05$. The compensation variable does not affect employee performance. The resulting t-statistic value is $0.815<1.96$, and the probability is $>0.05$. Work environment variable does not affect employee performance; the resulting t-statistic value is $1.303<1.96$, and probability $>0.05$.

\section{Indirect Effect or Mediation Test}

[Table 6 about here.]

Based on the table above, it can be concluded that:

Compensation $\rightarrow$ Work Motivation $\rightarrow$ Employee Performance of 0.166 with a t-statistic value of 2.453 and $5 \%$ of significance

Work Environment -> Work Motivation -> Employee Performance 0.237 with a t-statistic value of 2.564 and $5 \%$ of significance

Compensation -> Work Motivation -> Work passion 0.135 with a t-statistic value of 2.531 and $5 \%$ of significance

Environment -> Work Motivation -> Work passion 0.194 with a t-statistic value of 2.845 and $5 \%$ of significance

Leadership Style -> Work Motivation -> Employee Performance of 0.041 with a t-statistic value of 1.192 and a significance of 0.234 . Because the significance $>0.05$, it can be concluded that there is no mediation relationship. Leadership Style -> Work Motivation -> Work passion of 0.033 with a tstatistic value of 1.197 and a significance of 0.232 . Because the significance> 0.05 , it can be concluded that there is no mediation relationship.

\section{Predictive Relevance Test}

\section{[Table 7 about here.]}

The calculations in Table 7 (Q2) show the values of 0.460 and 0.404 so that it can be concluded that the model has a relevant predictive value.

\section{Fit Model Evaluation}

Fit Model, The evaluation in this study applied the Normal Fit Index (NFI) test model.

[Table 8 about here.]

The results showed that the saturated model's value (measurement) fit and the estimate model's value (structural model) had the same value. From these results, it can be concluded that the model in the study has a normal fit index (NFI) value, which indicates that the model in this study is $78.7 \%$ better than the null model.

\section{DISCUSSION}

\section{The Effect of Compensation on Motivation}

The results of this study indicate that the compensation variable has a significant effect on motivation. The way of providing management compensation is seen from the direct benefits that are felt. The greater the compensation provided by management, the greater the motivation of employees to improve their performance. This is the same as the research findings of Adeoye \& Elegunde (2014) that compensation and motivation management must be very basic for organizations in facilitating the achievement of goals. The results of this study also prove the correctness of existing theories; motivation is a condition that drives to be able to achieve the goals of motivation (Mangkunegara, 2004: 93).

\section{The Effect of Compensation on Passion to work}

The results of this study indicate that the compensation variable has a significant effect on work passion. So, the compensation provided by the company can increase work passion. The greater the compensation given, the greater the employee's work passion. Employee enthusiasm supports the smooth running of work which is the main task and function in the company or organization. In line with research conducted by Danti, F.P, M. Hakam, and M. Gambling Mukzam (2014), employees will feel enthusiastic about working if the company gives an award to its employees who can work well. Employees get income that can meet their daily needs in the form of a salary. Still, compensation can provide stimulation to 
employees so that employees get other income beyond the basic salary they receive each month. This result is also in line with the theory of Alex S. Nitisemito (2005: 153), which stated that compensation is the most effective system as a driving force that can bind and at the same time lead to work passion.

\section{The Effect of Work Environment on Work Motivation}

The results of this study indicate that the work environment variable has a significant effect on work motivation. It can be interpreted that the more comfortable the work environment is, the more employees will have high motivation. The results of this study are supported by the research carried out by (Haryani, Hamid, \& Susilo, 2015), which stated that the results of data analysis show that compensation has a significant effect on work motivation. In addition, according to Shidhaye R.V et al. (2011), the company provides a comfortable work environment because the work environment is an important factor in maintaining employee work passion. The work environment has a tremendous influence on an individual; it will have a big effect on what is done. The physical condition of a work environment has a big influence on the level of employee work passion.

\section{The Effect of Work Motivation on Employee Performance}

The results of this study indicate that the work motivation variable has a significant effect on employee performance. The motivation given by the company has a positive and significant impact on employee performance. Management's motivation can be an impetus for employees to work harder and enthusiastically to achieve oPT.imal results. The better the motivation is given, the better the performance. This study's results align with research conducted by Febrianti, Silfia (2014); Tampi (2014); Zameer, Hashim. Et al. (2014); Fomengky (2014); Juniantara, I. (2015); and Omollo, Pamela A. (2015) show that motivation has a significant effect on employee performance. However, these results are not in line with Susanti, A. and Baskoro, S. W. (2012); and Dhermawan, Sudibya, and Utama (2012), which show that work motivation has a positive and insignificant effect on performance. This study also proves Simamora's theory (in Mangkunegara, 2005: 14), which stated a relationship between work motivation and performance.

\section{The Influence of Work Motivation on Work Passion}

This study indicates that the work motivation variable has a significant effect on employee work passion. The motivation given by the company is seen from the direct benefits felt by employees, which has a positive and significant impact on employee work passion. Motivation can be a driving force for employees always to be enthusiastic at work. The better the motivation carried out by management to employees, the higher the employees' work enthusiasm. The results of this study are supported by research conducted by (Arranirti \& Izatunnisa, 2018) that work motivation has a significant effect on work passion.

\section{The Influence of Leadership Style on Employee Performance}

The results of this study indicate that the variable leadership style does not affect employee performance. Implementing the leadership style in this company does not affect employee performance and is also not a significant factor in improving performance. This research is in line with Marjaya, I, and F. Pasaribu (2019) 's research results, which show that leadership variables have a negative and insignificant effect on employee performance.

\section{The Influence of Leadership Style on Work Motivation}

The results of this study indicate that the leadership style variable does not affect work motivation. In other words, the leadership style adoPT.ed by managers and supervisors has a negative impact on employee motivation. The better the leadership style applied by managers and supervisors to employees, the performance results are not certain to increase. This study's results are in line with Sibali, N. D. (2011), which shows that leadership does not affect employee motivation. However, the results of this study contradict a number of theories, including (Fikri, 2008) which stated that without effective leadership, individuals or groups tend to be directionless, dissatisfied, and less motivated. (Kartono 2008) said that leadership style has a strong influence on motivation because the success of a leader in moving others to achieve a goal depends on how the leader creates motivation in each employee.

\section{The Influence of Leadership Style on Work Passion}

The results of this study indicate that the variable leadership style has no effect on work passion. It can be concluded that the leadership style applied by managers and supervisors that employees feel have a negative impact on work passion. The better the leadership style that is applied, the work passion will not certainly increase. This contradicts the results of the research conducted by Tarlis. A (2017) stated that a good leadership style could encourage employees' work passion so that they will be more productive, effective.

\section{The Effect of Compensation on Employee Performance}

The results of this study indicate that the compensation variable does not affect employee performance. This means that the compensation provided by the company cannot improve employee performance. Pradita (2017) found that compensation has a significant negative effect on performance. However, this finding contradicts Mondiani's theory (2012), which stated that the purpose of compensation management is to help the company achieve its strategy's success goals and ensure the creation of external and internal justice. Compensation is a policy in a company that is very important and strategic because its impact is directly related to increased work passion and employee performance in a company.

\section{The Effect of Work Environment on Employee Performance}

The results of this study indicate that work environment variables do not affect performance. It can be concluded that a comfortable work environment cannot improve employee performance. This study's results contradict the results of research conducted by Mahardiani and Pradhanawati (2013), which showed that the physical environment affects employee 
performance in outsourcing employees. The workspace is uncomfortable, hot, inadequate air circulation, the workspace is too dense, the work environment is not clean, and noise will affect employees' work comfort.

\section{The Effect of Compensation on Employee Performance Through Work Motivation}

This study's results indicate that the compensation variable has a positive and significant impact on the performance of the employees of PT. EX through work motivation, which can be proven from the value of the indirect effect through motivation which is greater than the direct effect on employee performance. This study's results are in line with research conducted by Puri, K. P, A. Suddin, and Suprayitno (2016), showing that motivation mediates the effect of compensation on employee performance, meaning that motivation affects the relationship between compensation and employee performance at PD BPR Bank Solo.

\section{Environmental Influence on Employee Performance Through Work Motivation}

This study indicates that the work environment variable has a positive and significant effect on the performance of the employees of PT. EX through work motivation. This means that the work environment can motivate employees to improve performance. This is in line with research conducted by Moulana, F., Bambang S., and Sunuhary. HNU. (2017), who found the work environment has an indirect influence on employee performance through work motivation. Work motivation is proven as an intervening variable/variable that strengthens the influence of the work environment on employee performance.

\section{The Effect of Compensation on Employee Performance Through Work Motivation}

This study indicates that the compensation variable has a positive and significant effect on work passion through work motivation. It can be concluded that good, fair, and fair compensation will motivate employees to work more enthusiastically. By giving compensation that is appropriate and fair will make PT. EX employees. They are motivated to increase their passion for work. The results of this study are supported by research conducted (Sunaryo, 2018) showing that Organizational Culture has a significant effect on Work Motivation, Compensation has a significant effect on Work Motivation, Organizational Culture has a significant effect on Work Passion, and compensation has a significant effect on Work Passion.

\section{The Influence of Environment on Passion through Work Motivation}

The results of this study indicate that environmental variables have a positive and significant effect on work passion through work motivation. It can be concluded that the environment at PT. EX is good enough so that it can motivate employees to work more enthusiastically. This result is in line with research conducted by Moulana, F., Bambang S., and Sunuhary. HNU. (2017) which stated that the work environment has an indirect effect on employee performance through work motivation.

The Influence of Leadership Style on Employee Performance Through Work Motivation

The results of this study indicate that the leadership style variable has no effect on work passion through work motivation. So, it can be concluded that there is no mediation relationship. This means that the applied leadership style cannot motivate the employees of PT. EX on performance. In other words, motivation cannot mediate the relationship between leadership style and employee performance. This contrasts with research conducted by IFajrin and Heru (2018), which found that work motivation mediates authoritarian leadership styles, participatory leadership styles, and delegation leadership styles on employee performance.

\section{The Influence of Leadership Style on Passion through Work Motivation}

This study indicates that the leadership style variable does not affect work passion through work motivation. Therefore, it can be concluded that there is no mediation relationship. This result contradicts Hasibuan's theory (in Sunaryo, 2018) which stated that motivation is the provision of a driving force that creates a person's enthusiasm for work so that they are willing to work together, work effectively, and are integrated with all their strengths and efforts to achieve satisfaction. Motivation is important because motivated employees will feel happier, healthier, and more enthusiastic at work.

\section{CONCLUSIONS}

Based on the analysis carried out by researchers in the field, it can be concluded as follows:

Compensation provided by management has a positive and significant impact on employee motivation. The greater the compensation was given, the greater the employee's motivation to improve their performance.

Compensation provided by the company can increase work passion. The greater the compensation provided by management, the higher the employee's work enthusiasm.

The work environment has a tremendous impact on an individual. The physical condition of a work environment has a big influence on the level of employee work passion. The more comfortable the work environment is the higher the employee's motivation.

The work environment has a direct influence on the employees who carry out the production process. A work environment that focuses on employees can improve performance and vice versa, and an inadequate work environment can reduce performance.

Management's motivation can be a driving force for employees to work more actively and enthusiastically to achieve oPT.imal results. The better the motivation that management does to employees, the better the performance that the employees produce.

The motivation provided by management can be a driving force for employees always to be enthusiastic at work. The 
better the motivation is done, the higher the work passion that the employee generates.

The implementation of the leadership style in this company does not affect employee performance; besides that, it is also not a major factor in improving employee performance

The leadership style applied by managers and supervisors has a negative impact on employee motivation. The better the leadership style applied by managers and supervisors to employees does not necessarily increase employee motivation to improve their performance.

The leadership style applied by managers and supervisors that employees feel have a negative impact on work passion. The better the leadership style applied by managers and supervisors to employees, it does not mean that employee work passion also increases.
Motivation can mediate the relationship between compensation and work environment on employee performance and employee work passion. 


\section{REFERENCES}

Athoillah, A. (2017). Dasar-Dasar Manajemen. Bandung: CV Pustaka Setia.

Arranirti, I., \& Izatunnisa, R. (2018). Pengaruh Pemberian Insentif dan Motivasi Kerja terhadap Gairah kerja Karyawan. Indonesian Journal Of Strategic Management, 1.

Danti, Fajarini P,Moh.Soe'oed hakam,Moch.Djudi Mukzam .2014.Pengaruh Kompensasi terhadap Gairah kerja Karyawan(Studi pada Karyawan CV.Sejahtera, Pakisaji, Malang).Jurnal Administrasi Bisnis (JAB) Vol.9 No.2.h 1-9.

Dhermawan, A. A. N. B., I. G. A. Sudibya, dan I. W. M. Utama. 2012. Pengaruh Motivasi, Lingkungan Kerja, Kompetensi, dan Kompensasi Terhadap Kepuasan Kerja dan Kinerja Pegawai di Lingkungan Kantor Dinas Pekerjaan Umum Provinsi Bali. Journal Manajemen, Strategi Bisnis dan Kewirausahaan 6(2): 173-184.

Fikri. 2008. Pengaruh Tipe Kepemimpinan dan Budaya Organisasi Terhadap Motivasi Kerja Pegawai Kecamatan Lowokwaru Kota Malang. Jurnal Aplikasi Manajemen 6(1): 98-103.

Fomenky, N. F. 2015. The Impact Of Motivation On Employee Performance. Global Conference Business and Financial Proceedings 10(1): 332-336.

Hasibuan, M. S. P. 2009. Manajemen Sourcedaya Manusia. Edisi Revisi. PT. Bumi Aksara. Jakarta.

Haryani, S. S., Hamid, D., \& Susilo, H. (2015). Pengaruh Kompensasi terhadap Motivasi Kerja dan Kinerja (Studi pada karyawan PT. TELKOMUNIKASI INDONESIA, TBK MALANG. Jurnal Administrasi Bisnis, 1.

Kartono, K. 2008. Pemimpin dan Kepemimpinan. Raja Grafindo Persada. Jakart

Mangkunegara, A. A. A. P. 2004. Manajemen Source Daya Manusia Perusahaan. Refika Aditama. Bandung

Mahardiani, Yoanisa dan Pradhanawati, Ari.2013. Pengaruh Stres Kerja dan Lingkungan Fisik Terhadap Kinerja

Karyawan OutsourcingPada PT.. Bank Jateng Cabang Koordinator dan Cabang Pembantu Wilayah Kota Semarang.Jurnal

Administrasi BisnisVol. 2 (1)

Marjaya, I dan F. Pasaribu. 2019. Pengaruh Kepemimpinan, Motivasi, Dan Pelatihan Terhadap Kinerja Pegawai, Maneggio: Jurnal Ilmiah Magister Manajemen. Vol 2 (1) 129-147

Moulana, F., Bambang S. dan Sunuhary. H.N.U. (2017). Pengaruh Lingkungan Kerja Terhadap Kinerja Karyawan Melalui Variabel Mediator Motivasi Kerja (Studi Pada Karyawan PT.. Telkom Indonesia,Tbk Witel Jatim Selatan, Jalan A. Yani, Malang). Jurnal Administrasi Bisnis (JAB)|Vol. 44 (1) 178 - 185.

Murtisaputra, E., \& Ratnasari, S. L. (2018). Pengaruh Lingkungan Kerja, Insentif, Komunikasi dan Senioritas terhadap Gairah kerja Karyawan . Jurnal Dimensi, 438.

Nitisemito, Alex S. 2005. Manajemen Personalia Manajemen Source DayaManusia. Jakarta: PT.. Ghalia

Ommolo, P. A. 2015. Effect of motivation on employee performance of commercial banks in Kenya: A case study of Kenya Commercial Bank in Migori County. International Journal of Human Resource Studies 5(2): 87-103.

Pradita. 2017. Pengaruh Kompensasi, Gaya Kepemimpinan dan Karakteristik Tenaga Pemasar Terhadap Motivasi dan Kinerja Tenaga Pemasar Pada PT.. Bank Rakyat Indonesia (Persero) Tbk. Cabang Jombang. Jurnal Bisnis dan Manajemen. Vol. 4 (2). p 153-164

Prasetyo, N. 2012. Pengaruh Gaya Kepemiminan dan Kompensasi Terhadap Motivasi Kerja Karyawan Hotel Muria Semarang. Dinamika Kepariwisataan XI(2): 32-39.

Puri, K. P, A. Suddin, dan Suprayitno (2016). Pengaruh Kompensasi Terhadap Kinerja Karyawan Dengan Motivasi Sebagai Variabel Mediasi (Survei Pada Karyawan PD. Bpr Bank Solo). Jurnal Ekonomi dan Kewirausahaan. Vol. 16 Edisi Khusus. 150 $-158$

Safriana, N., \& Lestari, V. (2019). Pengaruh Lingkungan Kerja terhadap Gairah kerja guru pada SMK NEGERI 1 UKUI. Jurnal Niara, 167.

Shidhaye R.V, dkk, 2011. Influence Of Working Condition On Job Satisfaction In Indian Anesthesiologists:A Cross Sectional Survey. Indian Institute Of Public Health Journal. 15(1):pp:30-37.

Sibali, N. D. 2011. Pengaruh Perubahan Gaya Kepemimpinan, Serta Implikasinya Terhadap Motivasi Karyawan Pada Perusahaan Tambang PT.. Kaltim Prima Coal Sangata Kalimantan Timur Pasca Perubahan Kepemilikan. Jurnal Eksis. 7(2): 19161922.

Tampi, B. J. 2016. Pengaruh Gaya Kepemiminan dan Motivasi Terhadap Kinerja Karyawan Pada PT.. Bank Negara Indonesia, Tbk (Regional Sales Manado). Journal “Acta Diurna” III(4): 1-20.

Tarlis. A. 2017. Pengaruh Gaya Kepemimpinan Terhadap Gairah kerja Karyawan Pada Bank Mandiri Cabang Langsa.

Zainun, B. (1991). Admistrasi dan Manajemen Kepegawaian Pemerintah Negara Indonesia. Jakarta : Gunung Agung.

Zainun, B. (1991). Admistrasi dan Manajemen Kepegawaian Pemerintah Negara Indonesia. Jakarta : Gunung Agung.

Zameer, H., S. Ali, W. Nisar, dan M. Amir. 2014. The impact of the motivation on the employee's performance in beverage industry of Pakistan. International Journal of Academy Research in Accounting, Finance \& Management Sciences 4(1): 293298. 
Conflict of InterestStatement:The authorsdeclare that theresearch wasconducted in the absence of any commercial or financial relationships that could be construed as a potential conflict of interest.

Copyright $(C)$ tahun terbit nama belakang and nama belakang. This is an open-access article distributed under the terms of the Creative Commons Attribution License (CC $B Y)$. The use, distribution or reproduction in other forums is permitted, provided the original author(s) and the copyright owner(s) are credited and that the original publication in this journal is cited, in accordance with accepted academic practice. No use, distribution or reproduction is permitted which does not comply with these terms. 


\section{LIST OF FIGURES}

1 Research Model 


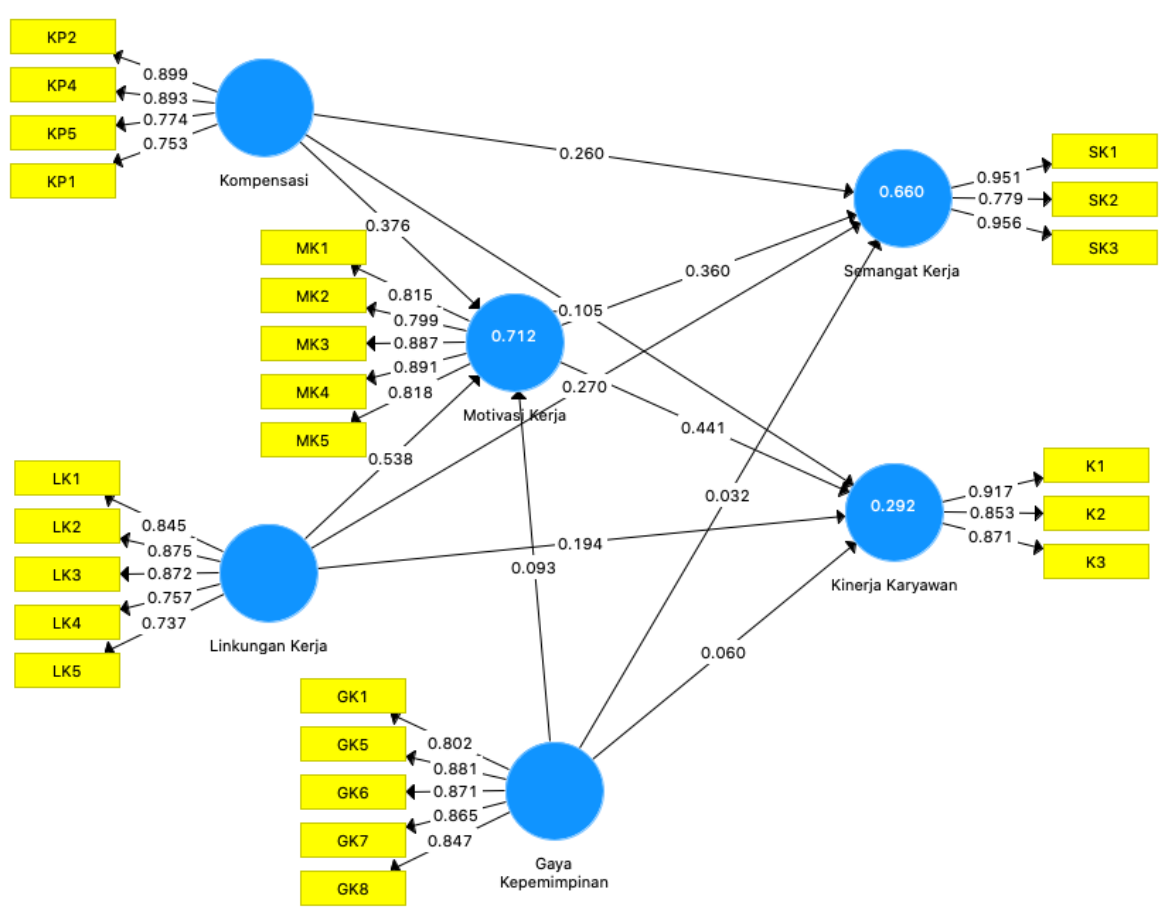

Source: Processed data, 2021

Figure 1 | Research Model 


\section{LIST OF TABLES}

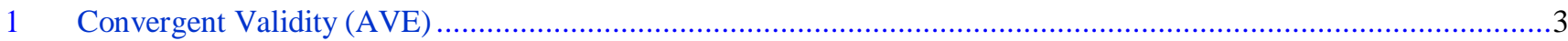

2 Discriminant Validity Test Results (Fornell-Larcker Criterion) ….................................................................. 3

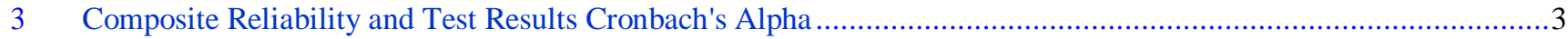

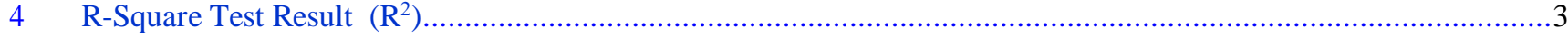

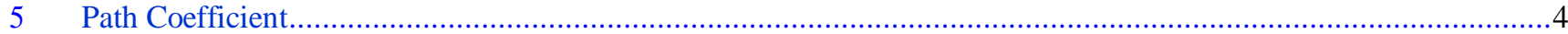

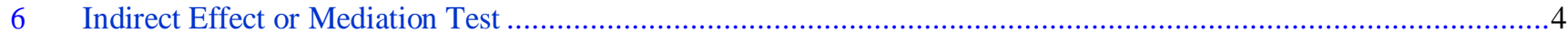

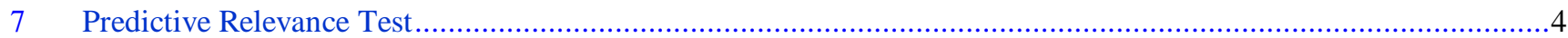

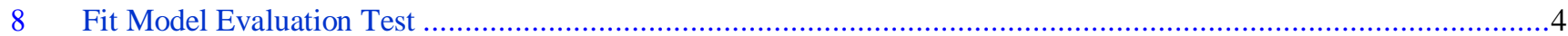


TABLE 1 / Convergent Validity (AVE)

\begin{tabular}{lcc}
\hline Leadership Style & $\begin{array}{c}\text { Average Variance } \\
\text { Extracted (AVE) }\end{array}$ & Keterangan \\
\hline Employee performance & 0,728 & Valid \\
\hline Compensation & 0,776 & Valid \\
\hline Work environment & 0,693 & Valid \\
\hline Work motivation & 0,671 & Valid \\
\hline Spirit at work & 0,710 & Valid \\
\hline
\end{tabular}

Processing Output withSmartPLS 3.0. 
TABLE 2 / Discriminant Validity Test Results (Fornell-Larcker Criterion)

\begin{tabular}{lcccccc}
\hline & $\begin{array}{c}\text { Leadership } \\
\text { Style }\end{array}$ & $\begin{array}{c}\text { Employee } \\
\text { performan } \\
\text { ce }\end{array}$ & $\begin{array}{c}\text { Compensatio } \\
\mathrm{n}\end{array}$ & $\begin{array}{c}\text { Work } \\
\text { Environme } \\
\text { nt }\end{array}$ & $\begin{array}{c}\text { Work } \\
\text { Motivati } \\
\text { on }\end{array}$ & $\begin{array}{c}\text { Work } \\
\text { passion }\end{array}$ \\
\hline $\begin{array}{l}\text { Leadership } \\
\text { Style }\end{array}$ & $\mathbf{0 , 8 5 3}$ & & & & & \\
$\begin{array}{l}\text { Employee } \\
\text { performance }\end{array}$ & 0,099 & $\mathbf{0 , 8 8 1}$ & & & \\
$\begin{array}{l}\text { Compensati } \\
\text { on }\end{array}$ & 0,027 & 0,354 & $\mathbf{0 , 8 3 2}$ & & \\
$\begin{array}{l}\text { Work } \\
\text { environment }\end{array}$ & $-0,010$ & 0,472 & 0,671 & $\mathbf{0 , 8 1 9}$ & & \\
$\begin{array}{l}\text { Work } \\
\text { motivation }\end{array}$ & 0,097 & 0,523 & 0,739 & 0,789 & $\mathbf{0 , 8 4 3}$ & \\
$\begin{array}{l}\text { work } \\
\text { passion }\end{array}$ & 0,071 & 0,501 & 0,708 & 0,729 & 0,769 & $\mathbf{0 , 8 9 9}$ \\
\hline
\end{tabular}

Source: Output processing with SmartPLS 3.0. 
TABLE 3 / Composite Reliability and Test Results Cronbach's Alpha

\begin{tabular}{lccl}
\hline & Cronbach's Alpha & Composite Reliability & Keterangan \\
\hline Leadership Style & 0,914 & 0,931 & Reliable \\
\hline $\begin{array}{l}\text { Employee } \\
\text { performance }\end{array}$ & 0,855 & 0,912 & Reliable \\
\hline Compensation & 0,850 & 0,900 & Reliable \\
\hline Work environment & 0,876 & 0,910 & Reliable \\
\hline Work motivation & 0,897 & 0,924 & Reliable \\
\hline Work passion & 0,878 & 0,926 & Reliable \\
\hline
\end{tabular}

Source: Output processing with SmartPLS 3.0. 
TABLE 4 / R-Square Test Result $\left(\mathrm{R}^{2}\right)$

\begin{tabular}{lcc}
\hline & R Square & R Square Adjusted \\
\hline Employee performance & 0,292 & 0,260 \\
\hline Work motivation & 0,712 & 0,702 \\
\hline Work passion & 0,660 & 0,645 \\
\hline
\end{tabular}

Source: Processing Output with SmartPLS 3.0. 


\begin{tabular}{|c|c|c|c|c|c|}
\hline & $\begin{array}{l}\text { Original } \\
\text { Sample } \\
\text { (O) }\end{array}$ & Mean (M) & $\begin{array}{l}\text { Standard } \\
\text { Deviation } \\
\text { (STDEV) }\end{array}$ & $\begin{array}{l}\text { T Statistics } \\
(|\mathrm{O} / \mathrm{STDEV}|)\end{array}$ & P Values \\
\hline $\begin{array}{l}\text { Leadership Style -> Employee } \\
\text { Performance }\end{array}$ & 0,060 & 0,072 & 0,120 & 0,503 & 0,615 \\
\hline $\begin{array}{l}\text { Leadership Style -> Work } \\
\text { Motivation }\end{array}$ & 0,093 & 0,081 & 0,068 & 1,362 & 0,174 \\
\hline Leadership Style -> work Passion & 0,032 & 0,032 & 0,072 & 0,442 & 0,659 \\
\hline $\begin{array}{l}\text { Compensation -> Employee } \\
\text { Performance }\end{array}$ & $-0,105$ & $-0,093$ & 0,129 & 0,815 & 0,415 \\
\hline $\begin{array}{l}\text { Compensation -> Work } \\
\text { Motivation }\end{array}$ & 0,376 & 0,372 & 0,074 & 5,115 & 0,000 \\
\hline Compensation -> work Passion & 0,260 & 0,253 & 0,101 & 2,580 & 0,010 \\
\hline $\begin{array}{l}\text { Work Environment -> Employee } \\
\text { Performance }\end{array}$ & 0,194 & 0,198 & 0,149 & 1,303 & 0,193 \\
\hline $\begin{array}{l}\text { Work Environment -> Work } \\
\text { Motivation }\end{array}$ & 0,538 & 0,539 & 0,059 & 9,102 & 0,000 \\
\hline $\begin{array}{l}\text { Work Environment -> work } \\
\text { Passion }\end{array}$ & 0,270 & 0,284 & 0,110 & 2,450 & 0,015 \\
\hline $\begin{array}{l}\text { Work Motivation -> Employee } \\
\text { Performance }\end{array}$ & 0,441 & 0,429 & 0,162 & 2,718 & 0,007 \\
\hline Work Motivation -> work Passion & 0,360 & 0,352 & 0,119 & 3,019 & 0,003 \\
\hline
\end{tabular}

Processing Output withSmartPLS 3.0. 


\begin{tabular}{|c|c|c|c|c|c|}
\hline & $\begin{array}{l}\text { Original } \\
\text { Sample (O) }\end{array}$ & $\begin{array}{c}\text { Sample } \\
\text { Mean (M) }\end{array}$ & $\begin{array}{l}\text { Standard } \\
\text { Deviation } \\
\text { (STDEV) }\end{array}$ & $\begin{array}{l}\text { T Statistics } \\
(|\mathrm{O} / \mathrm{STDEV}|)\end{array}$ & P Values \\
\hline $\begin{array}{l}\text { Leadership Style -> } \\
\text { Employee Performance }\end{array}$ & 0,041 & 0,035 & 0,034 & 1,192 & 0,234 \\
\hline \multicolumn{6}{|l|}{$\begin{array}{l}\text { Leadership Style -> Work } \\
\text { Motivation }\end{array}$} \\
\hline $\begin{array}{l}\text { Leadership Style -> Work } \\
\text { Passion }\end{array}$ & 0,033 & 0,029 & 0,028 & 1,197 & 0,232 \\
\hline $\begin{array}{l}\text { Compensation -> Employee } \\
\text { Performance }\end{array}$ & 0,166 & 0,158 & 0,068 & 2,453 & 0,015 \\
\hline \multicolumn{6}{|l|}{$\begin{array}{l}\text { Compensation -> Work } \\
\text { Motivation }\end{array}$} \\
\hline $\begin{array}{l}\text { Compensation -> Work } \\
\text { Passion }\end{array}$ & 0,135 & 0,131 & 0,053 & 2,531 & 0,012 \\
\hline $\begin{array}{l}\text { Work Environment -> } \\
\text { Employee Performance }\end{array}$ & 0,237 & 0,231 & 0,093 & 2,564 & 0,011 \\
\hline \multicolumn{6}{|l|}{$\begin{array}{l}\text { Work Environment -> } \\
\text { Work Motivation }\end{array}$} \\
\hline $\begin{array}{l}\text { Work Environment -> } \\
\text { Work Passion }\end{array}$ & 0,194 & 0,190 & 0,068 & 2,845 & 0,005 \\
\hline \multicolumn{6}{|l|}{$\begin{array}{l}\text { Work Motivation -> } \\
\text { Employee Performance }\end{array}$} \\
\hline $\begin{array}{l}\text { Work Motivation -> Work } \\
\text { Passion }\end{array}$ & & & & & \\
\hline
\end{tabular}

Source: Processing Output withSmartPLS 3.0. 
TABLE 7 / Predictive Relevance Test

\begin{tabular}{lccc}
\hline & SSO & SSE & $\mathrm{Q}^{2}(=1-\mathrm{SSE} / \mathrm{SSO})$ \\
\hline Leadership Style & 475,000 & 475,000 & \\
\hline Employee performance & 285,000 & 229,619 & 0,194 \\
\hline Compensation & 380,000 & 380,000 & \\
\hline Work environment & 475,000 & 475,000 & \\
\hline Work motivation & 475,000 & 240,924 & 0,493 \\
\hline Passion for work & 285,000 & 138,698 & 0,513 \\
\hline
\end{tabular}

Source: Processing Output withSmartPLS 3.0. 
TABLE 8 / Fit Model Evaluation Test

\begin{tabular}{ccc}
\hline & Saturated Model & Estimated Model \\
\hline NFI & 0,298 & 0,298 \\
\hline
\end{tabular}

Source: Processing Output with SmartPLS 3.0. 